\title{
Measuring the Impacts of Bus Rapid Transit on Residential Property Values:
}

\section{The Beijing Case}

\author{
Taotao Deng ${ }^{1^{*}}$, Mulan $\mathrm{Ma}^{2}$, John D. Nelson ${ }^{3}$
}

${ }^{1 *}$ School of Urban and Regional Science, Shanghai University of Finance and Economics, No. 777 Guoding Road, Shanghai, 200433, China

Phone: +86(0) 21 65904915, Email: deng.taotao@mail.shufe.edu.cn

2 School of Tourism and Event Management, Shanghai University of International Business and Economics, No. 1900 Wenxiang Road, Shanghai, 201620; China

3 Professor of Transport Studies, Director, Centre for Transport Research, University of Aberdeen, Fraser Noble Building, Aberdeen, UK, AB24 3UE 


\title{
Measuring the Impacts of Bus Rapid Transit on Residential Property Values: The Beijing Case
}

\begin{abstract}
Bus Rapid Transit (BRT) has emerged as a cost-effective transport system for urban mobility. The study uses the hedonic price model to investigate the impacts of BRT on residential property values in Beijing, where BRT has been in service for over 6 years. The empirical analysis suggests that BRT has positive impacts on surrounding property values. The hedonic price model shows that for every 100-m closer to the BRT station, asking prices of residential properties increase by between $1.32 \%$ and $1.39 \%$. The study suggests that accessibility improvement, rather than the type of transit system, has certain influence on property values. The paper underscores the importance of considering the application of value-capture tools to help finance BRT investments and calls for complementary investment policies to enhance property value impacts.
\end{abstract}

Key words: Bus Rapid Transit (BRT); Property Value Uplift; Accessibility; 


\section{Introduction}

Bus Rapid Transit (BRT) has emerged as a cost-effective transport system for urban mobility. The ability of BRT to provide significant transport improvement at low to medium costs within a short implementation time has prompted decision makers to rapidly deploy BRT schemes. Some countries have launched single lines, while others have implemented complete BRT networks (Deng and Nelson, 2011). These systems have achieved impressive outcomes in terms of social, economic, and environmental benefits, in spite of varying in size, design, service plan, operating features and technology application. Hensher (2007) indicates that BRT has the ability to deliver a high-quality service while costing much less than rail systems.

Although many BRT systems are successfully in operation across the world, it is arguable that the potential of BRT is not yet well understood by decision-makers. Since the implementation of modern BRT systems is relatively recent, there remains a lack of empirical evidence about what BRT can do for land development, except for a few places such as Bogotá where BRT has received extensive attention (Rodíguez and Targa, 2004; Rodríguez and Mojica, 2009; Munoz-Raskin, 2010). Bus services have long suffered from a negative image related to slow, polluting and unreliable service, which in turn cause stakeholders to hesitate to consider investing in BRT. In the report by the Transit Cooperative Research Program (TCRP), Christopher (2006) indicates that more research on land development benefits associated with BRT was needed, as such studies on BRT would improve the ability of government officials to negotiate with developers on dedicated BRT right-of-way and customer amenities. Recently, many cities have launched either a single BRT line or BRT network. Thus, the need for a clearer understanding of the economic impacts of BRT on land development is becoming increasingly important, especially as land value uplift conferred by BRT could be an incentive 
to encourage private financing in BRT projects.

This paper seeks to examine the extent to which accessibility improvements resulting from BRT have influenced surrounding property values. Our paper contributes to the literature in two aspects. Firstly, we make the argument of BRT-oriented development stronger, by introducing data from BRT implemented in China. Secondly, comparing proximity impacts from BRT in Beijing, Bogotá and Seoul, we explore possible operational features of BRT which may influence its impact on property value uplift.

The reminder of this paper is structured as follows. Section 2 reviews related literature about the impacts of BRT on property values, especially the quantitative effects. Section 3 provides background information on BRT implementation in Beijing, the first full-featured BRT line in China. Section 4 discusses the methodology and the data used. Section 5 presents the estimation results and compares findings with previous literature. Finally, section 6 draws conclusions and discusses the importance of the findings in a global approach to funding BRT infrastructures.

\section{Literature Review: The Impacts of BRT on Property Values}

There is considerable interest in measuring and exploiting property value uplift impacts conferred by transport investment. Ryan (1999) indicates that property values are likely to show a relationship with transport access, when transport investment provides actual travel time saving. Banister (2005) argues that this issue is crucially important, largely because the property value uplift effect associated with transport improvement can be used as an investment mechanism to finance transport projects. RICS (2002) completed a detailed literature review, amounting to over 150 references from UK, Europe and North America, on 
the relationship between land use, land value and public transport. The study concludes that rail-based systems (heavy rail, Metro and Light Rail Transit (LRT)) generally have positive impacts on the residential and commercial property markets, but the range of impacts varied significantly across municipalities. As for BRT, its main attraction to policy-makers is that it can be an affordable approach to moving a large number of people. Nevertheless, a full-featured BRT system generally requires significant investments in support of construction of exclusive busways and enhanced stations. Currie (2006) yet argues that modern BRT systems, like other forms of Mass Transit, such as Metro and LRT, have a strong capability to lead bus-based Transit Oriented Development.

Some significant land development effects around BRT stations were identified in Pittsburgh, Ottawa, Adelaide and Brisbane reviewed by Levinson et al. (2003); in Cleveland, Boston and Pittsburgh assessed by Diaz and Hinebaugh (2009); in Nantes, Rennes and Lorient reviewed by Rabuel (2010). While those reports provides qualitative evidence that BRT has positive effects on land development, some studies (summarized in Table 1) go beyond the qualitative approach in an attempt to quantify the impact of proximity to BRT on property values.

\section{INSERT TABLE 1}

Despite many BRT systems in operation, quantitative evidence on property value uplift effect resulted from BRT is still limited. While some well established BRT in Latin America have gained intensive attention, BRT experience in Asian cities has been less recorded.

In China, since the first full-featured BRT system was implemented in Beijing in the late 2004, up to now, BRT schemes have been implemented in 14 cities as one of key strategies for relieving traffic problems. Nevertheless, up to date, there has been no quantitative approach to estimating for impacts of BRT operation on property values in China. Given the meteoric 
increase in BRT deployments in China, it is important to provide a better understanding of its performance, especially the relationship between BRT and property value. Thus, this paper contributes to the literature by adding experience from evaluating BRT performance in Beijing, where BRT has been in service for over 6 years.

\section{Area of Study: Beijing BRT Line 1 Corridor}

Beijing is the political capital of China. With a population of 19.61 million in 2010, Beijing is one of the world's largest and fastest growing mega-cities. It has an area of $16,410 \mathrm{~km}^{2}$ and 18 districts under its jurisdiction (see Fig. 1). Beijing has a high population density of 23,407 people per $\mathrm{km}^{2}$ in the urban core area. The per capita GDP of urban residents was 75,943 Yuan/year ${ }^{1}$ in 2010, the second highest in China after Shanghai (Beijing Statistical Yearbook, 2011).

\section{INSERT FIGURE 1, 2}

Beijing Southern Axis BRT Line 1 is located in the Beijing southern area, which is relatively deprived and under-developed. The busway corridor is located in the middle of a north-south traffic artery. As Beijing continues its rapid expansion, this road becomes one of the important corridors connecting the city centre and the southern area. BRT Line 1 started trial operation in December 2004 and full operation in December 2005. The route starts at Qian`men (city centre) and ends at De`mao`zhuang (a southern residential area), running through 17 stations, shown in Fig. 2. To provide ready access to the larger Beijing transit network, the terminal station (Qian`men) of BRT Line 1 is located beside to a metro station. This BRT includes exclusive busway, improved stations, advanced vehicles, frequent service, rapid boarding, Intelligent Transportation Systems (ITS) application and off-board fare collection.

\footnotetext{
${ }^{1}$ Note: Yuan (RMB) designates the currency used in China.
} 
Since this rubber-tyred transit system has adopted many features of LRT to speed up vehicle and enlarge capacity, it has achieved almost $40 \%$ travel time reduction on average and high ridership (daily trips around 120,000 passengers, 3,800 passengers per hour per direction in a 15.8-km single corridor), with the capital cost (infrastructure and vehicle) of 40 million Yuan $(\mathrm{RMB}) / \mathrm{km}^{1}$. The articulated vehicle can move far more passengers than the conventional bus. The ridership of BRT is almost 4 times that of conventional bus services. Prior to its opening, conventional buses provided poor public transport services on the southern main road. The BRT Line 1 now offers a larger capacity and much faster connection for local residents and businesses in the southern area to downtown. Recently, the Beijing southern area has experienced high-speed urban development. Many poor quality buildings have been refurbished and some new residential developments have been built. According to a recent passenger survey (Deng and Nelson, 2012), this BRT has gained great popularity among passengers, despite some complaints. Encouragingly, this BRT has attracted some choice users who use BRT even though they have a car alternative, estimated by $12.4 \%$ of total surveyed passengers.

\section{Methodology and Data}

The Hedonic Price Model (HPM) has been commonly used to quantify the proximity effect of public transport on property value uplift (see Table 1). Origination of this model is generally credited to Rosen (1974). In real estate appraisal, it is assumed that property prices could be regressed on various variables of location, structural and neighbourhood-related housing attributes. The traditional HPM is specified as the following form:

$$
\mathbf{P}=\mathbf{X}_{1} \boldsymbol{\beta}_{1}+\mathbf{X}_{2} \boldsymbol{\beta}_{2}+\mathbf{X}_{3} \boldsymbol{\beta}_{3}+\varepsilon
$$

\footnotetext{
${ }^{1}$ Source: some latest data were derived from www.chinabrt.org. The capital cost of Beijing BRT line 1 is more expensive than other BRT projects in China, largely because of the construction of exclusive busways and stations. Another reason is that there was no previous experience in BRT planning in China and thus many of the planning works were developed for the first time.
} 
where $\mathbf{P}=$ is the vector of property prices

$\mathbf{X}_{\mathbf{1}}=\mathrm{a}$ vector of variables that describes location attributes (such as proximity to transit and highways and accessibility via highway and transit networks)

$\mathbf{X}_{\mathbf{2}}=\mathbf{a}$ vector of variables that describes structural attributes

$\mathbf{X}_{\mathbf{3}}=$ a vector of variables that describes neighbourhood attributes $\varepsilon=$ a vector of independent and identically distributed error terms.

\subsection{Data source}

The study focuses on residential properties because such data are more readily available. The most reliable data in measuring property value change is the transaction data recorded in statutory real estate exchange. However, these transactional data are normally highly sensitive and not open to the public. It proved to be very difficult to acquire comprehensive transactional data from the local government during the fieldwork in this research. Thus, the asking prices of residential projects (previously owned condominiums) along the BRT corridor were collected. A problem arose in our selection of appropriate residential projects. In order to improve urban mobility and provide better transport services, Beijing has implemented an ambitious Metro extension. Metro lines 4, 5 and L2 were implemented in the southern area. BRT line 1 is located in the middle of two subway lines, about 2-km distance to each subway line inside the $3^{\text {rd }}$ ring road. When Metro lines go beyond the $3^{\text {rd }}$ ring road, the location of the two Metro lines becomes much farther from the BRT line 1. Thus we selected condominiums within a 800-m buffer area of BRT stations and relatively far away from city centre and Metro, to rule out the possibility of benefits from the Metro extension. Totally we have sampled 233 condominiums from 18 communities through the field inspection in January and February 2012. Residential projects along BRT corridor consist of a number of high-density and middle income condominiums with mostly two-bedroom units, as shown in 
Fig. 3.

\subsection{Data description}

It is worth noting that the attributes preferred in previous studies estimating the impacts of BRT on property value change may not necessarily be identical in this case because of cultural differences. Based on the interviews with real estate agents during the field inspection and previous studies on variables selection as well as data availability, 13 variables were chosen for use. In this research, 2 variables describing location attributes (distance to the nearest BRT station, distance to the downtown), 5 variables describing structural attributes (floor area, floor level, interior decoration of the apartment, property age, number of bedrooms) and 6 variables describing neighbourhood attributes (property management fee of the community, the outside environment quality of the community, the quality of recreational and sports facilities in the community, supermarket, school, parkland) were used in the model. Those variables are commonly used variables in Chinese studies on measuring the proximity effect of public transport on property value uplift. For location attributes, we would expect that the smaller of the distance between a property and the BRT is, the higher of the property value is due to ease of access. We also expect that a property is located closer to downtown, the higher of the property value is. Table 2 presents descriptive statistics on variables used in the HPM.

INSERT TABLE 2

\section{Empirical results}

\subsection{Effect of proximity to BRT stations on residential property values}

In this study, semi-log specification was used in the HPM functional form. The semi-log specification transforms the dependent variable logarithmically, while the independent 
variables remain untransformed. The dependent variable (property prices) is expressed in natural logarithms in order to reduce volatility. To overcome heteroscedasticity problem ${ }^{1}$, two regression models were used. The first is an ordinary least squares (OLS) model with robust standard errors and the second is a weighted least squares (WLS) model. Table 3 presents regression results estimated from the model.

\section{INSERT TABLE 3}

Overall, the signs of the coefficients appear as expected, but some variables are not statistically significant at the $5 \%$ level of significance. The effect of distance to downtown is negative and highly significant in both OLS and WLS models. We found the DIST_BRT variable to be negative in sign and highly statistically significant. While the distance to the downtown increases, property prices fall. The quality of outside environment positively affect property. The nearby supermarket and parkland positively contribute to the property price. The coefficient for variable "property age" has a positive sign. A possible reason is that residential properties selected in this study were mostly established in the late 1990s. Those properties are considered as the same type of relatively new buildings in the second-hand property market. Compared with other important factors (such as property location, supermarket and parkland), the asking price does not reflect property age very well.

Turning to the variable of interest to us, the distance to a BRT station, we observe that its parameter estimate is negative and highly significant at the $1 \%$ level in both OLS and WLS models. It suggests that BRT has positive impacts on property value: as the distance from a BRT station increases, property values decreases, all else being equal. The coefficient estimated with the semi-log functional form shows that for every $100-\mathrm{m}$ closer to the BRT station, asking prices of residential properties increased by between $1.32 \%$ and $1.39 \%$.

\footnotetext{
1 The White test was used to text heteroscedasticity. The result (Prob>chi2 $=0.0000)$ suggests that the null hypothesis should be rejected. The White test concludes that heteroscedasticity is an issue.
} 


\subsection{Comparing findings with previous literature}

Empirical results from Beijing BRT Line 1 are consistent with the previous findings from BRT systems in Bogotá (Rodríguez and Targa, 2004; Munoz-Raskin, 2010) and Seoul (Cervero and Kang, 2011), which suggest that implementing a full-featured BRT system has positive impacts on property values. However, the magnitude of proximity impacts from Beijing BRT is relatively small in comparison with findings Bogotá and Seoul cases, shown in Table 4. Although BRT`s impacts on property value strongly depend on the scale of the transport investment, the economic climate and supportive public policy, Table 4 provide some basic context information which make the comparison clearer. The passenger volume of Beijing BRT Line 1 is significantly smaller than Bogotá and Seoul cases. Beijing BRT Line 1 links downtown to outskirt, while Bogotá BRT passes through downtown. Importantly, Beijing BRT Line 1 is a trunk-only line rather than a trunk-feeder system. Compared with Bogotá and Seoul cases, Beijing BRT Line 1 is not connected with other BRT lines or Metro network (except for the terminal station) to compose an efficient transit network. Thus the catchment areas of Beijing BRT are relative small and the magnitude of proximity impacts is relative small too.

\section{INSERT TABLE 4}

\section{Conclusions and Discussions}

The development of BRT, especially the full featured BRT systems, are relatively recent. An appropriately designed BRT system can add capacity to a transport corridor and save travel time, which could enhance its accessibility. In this case study, Beijing BRT Line 1 is a significant transport improvement to the southern area, which has greatly improved accessibility for condominiums along its route. Implementing a full-featured BRT system has 
the potential to improve the accessibility of property with proximity to BRT stations and the increased accessibility could be capitalized into the property market. The property value uplift effect was estimated by between $1.32 \%$ and $1.39 \%$, for every 100 -m closer to the BRT station. These findings support the arguments by Cervero and Kang (2011) that the comparative travel-time savings of taking transit vis-a-vis the private car, rather than the type of transit system, contributes to travel demand and development potential. Based on the empirical results reported in this paper, policy recommendations on future implementation of BRT are presented.

\subsection{Improve and encourage collaboration between developer and the local authority}

Polzin (1999) indicates that there are three ways that transport investment can influence land use: accessibility improvements, complementary policies, and "momentum and promotion"1. Transport accessibility enhancement is a major contributor to travel demand and development, complementary investment policies and creating momentum or expectations have also played an important role in enhancing land-use impacts. Thus, as Polzin and Baltes (2002) indicate, the magnitude of land-use impacts conferred from BRT significantly depends on the actions of the profession, funding agencies, and decision-makers toward leveraging the investment in BRT. As an economical public transport project, BRT, however, has received much less attention on funding issues than rail systems. To date, BRT projects are overwhelmingly funded by public revenue. The property value capture resulting from BRT projects has provided some revenue-generating opportunities, and thus could be considered as an important funding source contributing to BRT investment. In the case of Beijing, although BRT Line 1 has provided some revenue-generating opportunities, promoting land development around BRT stations was not within the scope of planners in the early planning

\footnotetext{
${ }^{1}$ Polzin (1999) indicates that creating momentum or expectations can draw attention to development opportunities near transportation facilities and thus have positive impacts on development.
} 
stage. Since the extent to which BRT is able to stimulate land development is highly dependent on the co-ordination among stakeholders, it requires government collaboration to facilitate and improve the integration of BRT and land development in major BRT stations at an early stage of development. For future implementation of BRT, it is suggested that the local authority should seriously considering applying value-capture tools to help finance BRT investments and actively look for joint development opportunities with developers in the planning stage. Zoning incentives such as appropriately increasing plot ratio and adjusting land-use types, for example, could be used to encourage high density development along transport corridors. There is already evidence that that some local authorities have realised the potential of BRT as a catalyst for land development, and attempted to attract private fund for financing BRT implementation. An early report for DfT (2008) in the UK shows that the BRT project (the second Fastrack route) was fully funded by the developer as part of a major mixed-use regeneration project in the Thames Gateway development in Kent.

\subsection{Physically improve service quality to enhance accessibility benefits}

Although the magnitudes of BRT`s affects on property value may vary from place to place, there are some measures which are helpful in enhancing accessibility benefits. As discussed in Table 1, significant proximity effects to BRT corridor were found. BRT systems in Bogotá and Seoul have median busways, attractively designed vehicles and bus stations, which can physically increase the appeal of the BRT and thus create a strong image among BRT passengers and potential riders. More importantly, Bogotá and Seoul`s median-lane BRT network are supported by extensive feeder buses, which has significantly enlarged their catchment areas. In addition, improving access environments around BRT stations, such as providing safe pedestrian roads and enhancing lighting, is also helpful to enhance accessibility benefits. Jiang et al (2012) suggests that people tend to walk farther to BRT 
stations when the walking environment has certain features, such as median transit-way station location and shaded corridors. Thus, in order to enhance BRT`s impacts on property values, the access environment to BRT stations needs to be well designed to materially improve service quality and enlarge catchment areas.

A point to note is that these findings were obtained from Beijing, which is characterized by relatively low income population and high-density development. While certain general findings may apply to other cities, it must be recognized that every city has its unique urban characteristics, travel behaviour, economic condition, political contexts and investment preference, therefore the interpretation of the above results make for cautious generalizations to other cities. There are two limitations of this study. One limitation is the sample size. A larger sample size can provide more robust results. Another limitation is the use of asking price to reflect transactional prices in the HPM analysis. The approach assumes that there is a high correlation between asking data and transactional data and this relationship remains constant over time and is not affected by economic cycles. It acknowledges that systematic bias in the difference between asking and transactional prices will bias the results, and thus future efforts should attempt to include satisfactory data on transactional prices.

It should be noted that this study was conducted just 6 years after the full operation of BRT service. The full impacts of BRT investment will take a much longer time to realize. In some cities, such as Curitiba, where BRT systems have been in service for decades, BRT is used as a tool for leading urban development. Thus, this research can be considered as an important step to the further analysis of the impact of Beijing BRT Line 1 on the southern area. 


\section{References}

Banister, D. (2005) Property values and public transport investment, Paper presented at the European Transport Conference 2005, October, Strasbourg.

Cervero, R. and Kang, C. D. (2011) Bus Rapid Transit Impacts on Land Uses and Land Values in Seoul, Korea, Transport Policy, 18 (1), 102-116.

Cervero, R. and Duncan, M. (2002) Land Value Impacts of Rail Transit Services in Los Angeles County, Report prepared for the National Association of Realtors and the Urban Land Institute.

Christopher, M. K. (2006) TCRP Synthesis 67: Bus Transit Service in Land Development Planning: A Synthesis of Transit Practice, Transportation Research Board, Washington, D.C Currie, G. (2006) Bus Transit Oriented Development—-Strengths and Challenges Relative to Rail, Journal of Public Transportation, 9(4), 1-21.

Deng, T. and Nelson, J. D. (2012) The Perception of Bus Rapid Transit: A Passenger Survey from Beijing Southern Axis BRT Line 1, Journal of Transportation Planning and Technology, $35(2), 201-219$.

Deng, T. and Nelson, J. D. (2011) Recent Developments in Bus Rapid Transit: A Review of the Literature, Transport Reviews, 31(1), 69-96.

Department for Transport (DFT) (2008) Building Sustainable Transport into New Developments: A Menu of Options for Growth Points and Eco-towns, www.dft.gov.uk/pgr/sustainable, (accessed in January 2012).

Diaz, R. B. and Hinebaugh, D. (2009) Characteristics of Bus Rapid Transit for Decision Making, Report to U.S. DOT, FTA and TRI, Washington.

Dubé, J., Rosiers, F. D., Thériault, M. and Dib, P. (2011) Economic impact of a supply change in mass transit in urban areas: A Canadian example, Transportation Research Part A, 45: $46-62$.

Jiang, Y., Zegras, C. and Mehndiratta, S. (2012) Walk the line: station context, corridor type and bus rapid transit walk access in Jinan, China, Journal of Transport Geography, 20, 1-14. 
Jun, M. J. (2012) Redistributive effects of bus rapid transit (BRT) on development patterns and property values in Seoul, Korea, Transport Policy, 19:85-92.

Hensher, D. A. (2007) Sustainable public transport systems: Moving towards a value for money and network-based approach and away from blind commitment, Transport Policy, 14, 98-102.

Hess, D. B. and Almeida, T. M. (2007) Impact of proximity to light rail rapid transit on station-area property values in Buffalo, New York, Urban Studies, 44 (5/6): 1041-1068.

Levinson, H., Zimmerman, S., Clinger, J., Rutherford, S., Smith, R. L., Cracknell, J. and Soberman R. (2003) TCRP Report 90: Bus Rapid Transit, Vol. 1, Case Studies in Bus Rapid Transit, Transportation Research Board of the National Academies, Washington, DC.

Perk, V. A. and Catalá, M. (2009) Land Use Impacts of Bus Rapid Transit: Effects of BRT Station Proximity on Property Values along the Pittsburgh Martin Luther King, Jr. East Busway, Report to U.S. DOT, FTA and TRI, Washington.

Polzin, S. E. and Baltes, M. R. (2002) Bus Rapid Transit: A Viable Alternative? Journal of Public Transportation, 5(2), 47-69.

Polzin, S. E. (1999) Transportation / Land-Use Relationship: Public Transit's Impact on Land Use, ASCE Journal of Urban Planning and Development, 125(4):135-151.

Rosen, S., (1974) Hedonic Prices and Implicit Markets: Product Differentiation in Pure Competition, Journal of Political Economy, 82(1): 34-55.

Munoz-Raskin, R. (2010) Walking accessibility to bus rapid transit: Does it affect property values? The case of Bogota', Colombia, Transport Policy, 17, 72-84.

Rabuel, S. (Ed.), (2010). Buses with a high level of services: Choosing and implementing the right system. Lyon: Certu.

Rodíguez, D. A. and Targa, F. (2004) Value of accessibility to Bogotá's Bus Rapid Transit system, Transport Reviews, 24(5): 587-610.

Rodríguez, D. A. and Mojica, C. H. (2009) Capitalization of BRT network expansions effects into prices of non-expansion areas, Transportation Research Part A, 43, 560-571. 
Royal Institution of Chartered Surveyors (RICS) (2002) Land Value and Public Transport: Stage 1 - Summary of findings, Report to Royal Institution of Chartered Surveyor and Office of the Deputy Prime Minister.

Ryan, S. (1999) Property Values and Transportation Facilities: Finding the Transportation Land Use Connection, Journal of Planning Literature, 13 (4): 412-427. 


\section{Figures}

Fig. 1: The administrative area of Beijing

Fig. 2: The route and stations of Beijing BRT Line 1

Fig. 3: Typical condominiums along the BRT corridor 


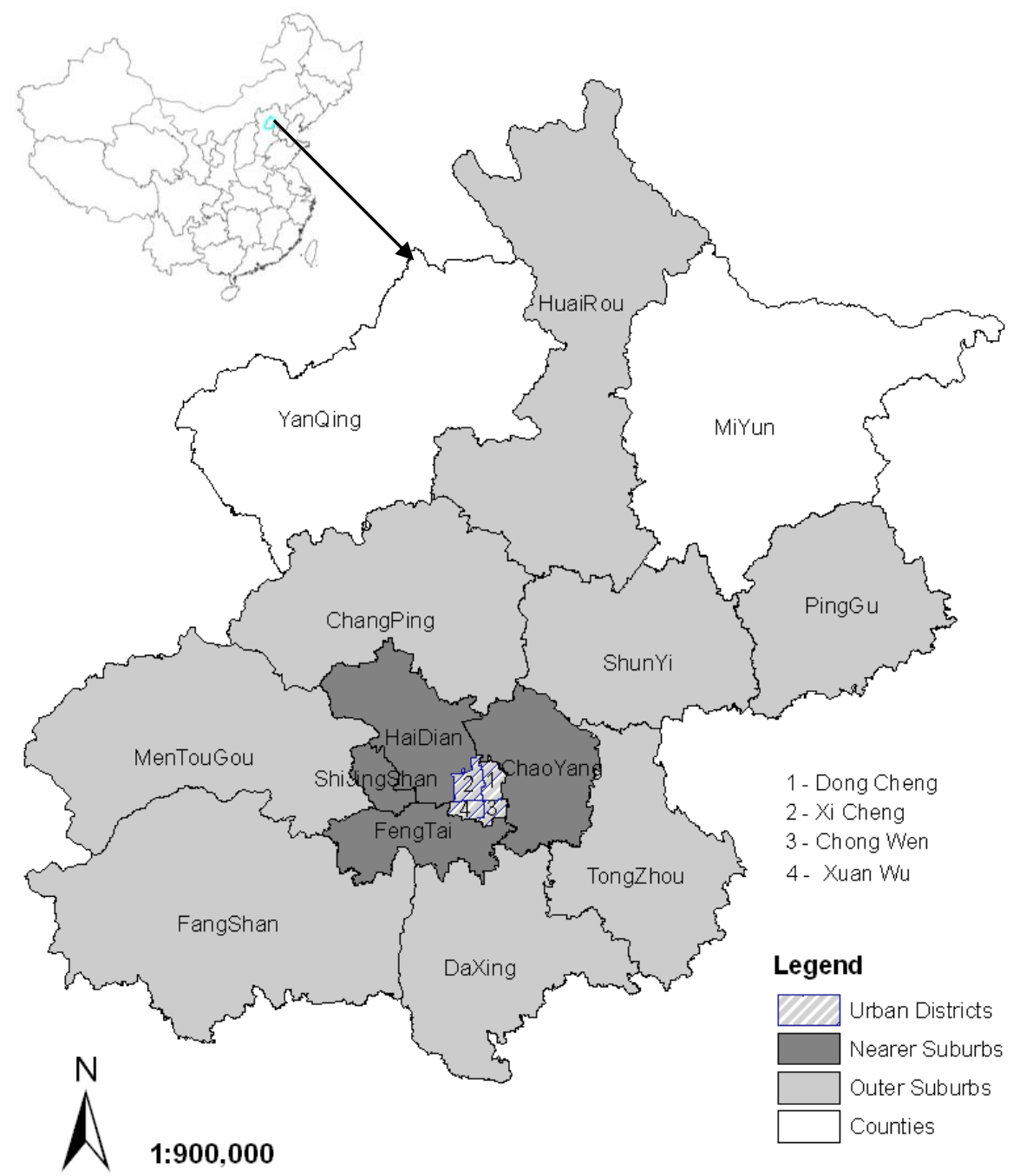

Fig. 1: The administrative area of Beijing 


\section{City Centre}

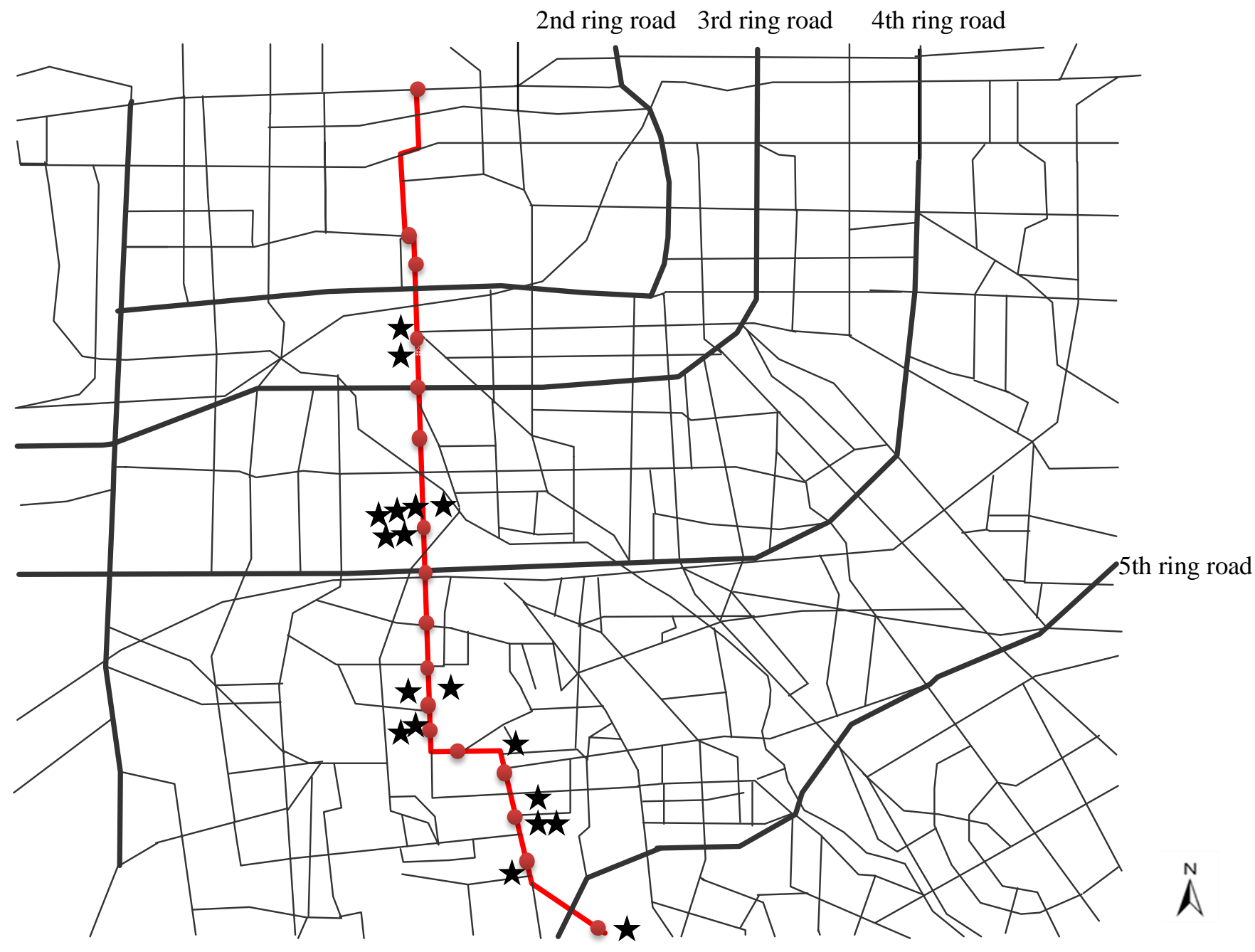

- BRT station $\star$ Surveyed communities

—Express way and BRT route - Minor arterial

Fig. 2: The route and stations of Beijing BRT Line 1 

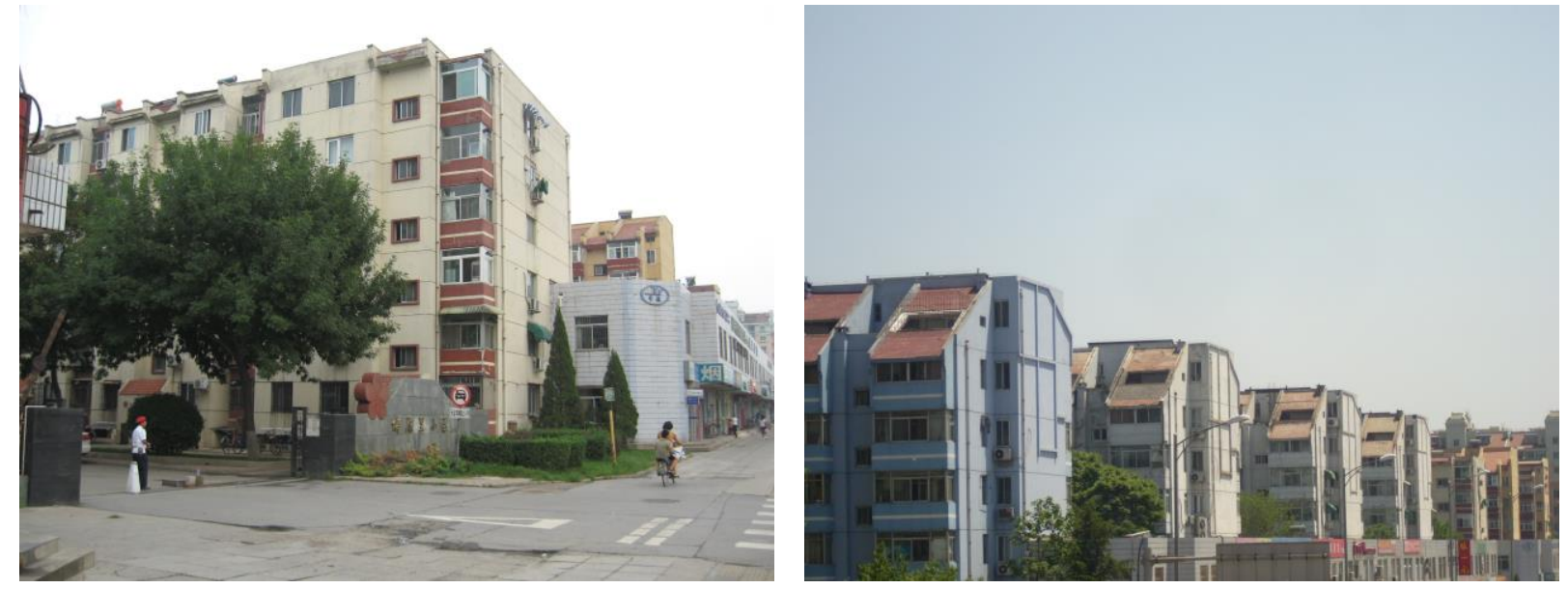

Fig. 3: Typical condominiums along the BRT corridor (Photo taken by authors) 


\section{Tables}

Table 1: Quantitative studies on property value uplift impact from BRT systems

Table 2: Description of variables and summary statistics

Table 3: Hedonic Price Model results: factors influencing property values

Table 4: Comparison of proximity effects to BRT systems in Beijing, Bogotá and Seoul 
Table 1: Quantitative studies on property value uplift impact from BRT systems

\begin{tabular}{|c|c|c|c|c|c|}
\hline BRT system & Methodology & Property type & Data & Property value impacts & Reference \\
\hline \multirow{3}{*}{$\begin{array}{l}\text { Bogotá } \\
\text { TransMilenio } \\
\text { (opened in 2000) }\end{array}$} & HPM & $\begin{array}{l}\text { multifamily } \\
\text { residential } \\
\text { properties }\end{array}$ & $\begin{array}{l}\text { residential } \\
\text { rents }\end{array}$ & $\begin{array}{l}\text { After only 2-years operation of BRT, residential rental costs increased by } \\
6.8-9.3 \% \text { for every } 5 \text { minutes walking time to BRT stations. }\end{array}$ & $\begin{array}{l}\text { Rodíguez and } \\
\text { Targa (2004) }\end{array}$ \\
\hline & $\begin{array}{l}\text { before - after } \\
\text { HPM }\end{array}$ & $\begin{array}{l}\text { single-family } \\
\text { and } \\
\text { condominiums }\end{array}$ & $\begin{array}{l}\text { asking } \\
\text { prices }\end{array}$ & $\begin{array}{l}\text { Network effects were found from the extension of BRT. The asking price } \\
\text { of properties in the BRT catchment area was found between } 7 \% \text { and } 14 \% \\
\text { higher than that in the control area. }\end{array}$ & $\begin{array}{l}\text { Rodríguez and } \\
\text { Mojica (2009) }\end{array}$ \\
\hline & HPM & $\begin{array}{l}\text { residential } \\
\text { properties }\end{array}$ & $\begin{array}{l}\text { asking } \\
\text { prices }\end{array}$ & $\begin{array}{l}\text { Property value premium for proximity to BRT was found on } \\
\text { middle-income properties but not on low-income housing. }\end{array}$ & $\begin{array}{l}\text { Munoz-Raski } \\
\text { n (2010) }\end{array}$ \\
\hline $\begin{array}{l}\text { Pittsburgh } \\
\text { East Busway } \\
\text { (opened in 1983) }\end{array}$ & HPM & $\begin{array}{l}\text { single-family } \\
\text { house }\end{array}$ & $\begin{array}{l}\text { assessed } \\
\text { prices }\end{array}$ & $\begin{array}{l}\text { Significant proximity effects to BRT corridor were found: a property } 100 \\
\text { feet away from a BRT station was valued about } \$ 9,745 \text { more than a } \\
\text { property } 1,000 \text { feet away*. }\end{array}$ & $\begin{array}{l}\text { Perk and } \\
\text { Catalá (2009) }\end{array}$ \\
\hline $\begin{array}{l}\text { Los Angeles } \\
\text { Metro Rapid } \\
\text { BRT (opened in } \\
\text { 2000) }\end{array}$ & HPM & $\begin{array}{l}\text { residential and } \\
\text { commercial } \\
\text { properties }\end{array}$ & $\begin{array}{l}\text { assessed } \\
\text { prices }\end{array}$ & $\begin{array}{l}\text { BRT has small negative impacts on residential property values and } \\
\text { positive impacts on commercial parcels. The absence of dedicated } \\
\text { right-of-way, the newness of the service (only one year) and lying in } \\
\text { distressed inner-city settings accounted for lower property value. }\end{array}$ & $\begin{array}{l}\text { Cervero and } \\
\text { Duncan } \\
(2002)\end{array}$ \\
\hline \multirow{2}{*}{$\begin{array}{l}\text { Seoul BRT } \\
\text { (opened } \\
\text { in 2004) }\end{array}$} & $\begin{array}{l}\text { Multilevel } \\
\text { logit model } \\
\text { and HPM }\end{array}$ & $\begin{array}{l}\text { residential and } \\
\text { non-residential } \\
\text { land values }\end{array}$ & $\begin{array}{l}\text { assessed } \\
\text { prices }\end{array}$ & $\begin{array}{l}\text { Land use along BRT corridors was intensified. Within } 300 \text { metres of BRT } \\
\text { stations, residential land values gained premiums ranging from } 5 \% \text { to } \\
10 \% \text {; within } 150 \text { metres of BRT stations, non-residential land values } \\
\text { gained premiums varying between } 3 \% \text { and } 26 \% \text {. }\end{array}$ & $\begin{array}{l}\text { Cervero and } \\
\text { Kang (2011) }\end{array}$ \\
\hline & $\begin{array}{l}\text { urban } \\
\text { simulation } \\
\text { model }\end{array}$ & $\begin{array}{l}\text { residential and } \\
\text { non-residential } \\
\text { locations }\end{array}$ & $\begin{array}{l}\text { monthly } \\
\text { rents }\end{array}$ & $\begin{array}{l}\text { BRT contributes to increased development density in urban centres. } \\
\text { BRT has more significant redistributive effects on non-residential } \\
\text { activities than residential activities. }\end{array}$ & Jun (2012) \\
\hline $\begin{array}{l}\text { Quebec City } \\
\text { Métrobus } \\
\text { ( opened in 1992) }\end{array}$ & $\begin{array}{l}\text { difference-in- } \\
\text { differences }\end{array}$ & $\begin{array}{l}\text { single-family } \\
\text { house }\end{array}$ & $\begin{array}{l}\text { sales } \\
\text { transaction } \\
\text { data }\end{array}$ & $\begin{array}{l}\text { BRT has generated an increase in house price ranging from } 6.9 \% \text { to } \\
2.9 \% \text {, for those properties located close to the service corridor. }\end{array}$ & $\begin{array}{l}\text { Dubé et al } \\
(2011)\end{array}$ \\
\hline
\end{tabular}

* Perk and Catalá (2009) acknowledges that some factors introducing may upward bias the key results. 
Table 2: Description of variables and summary statistics

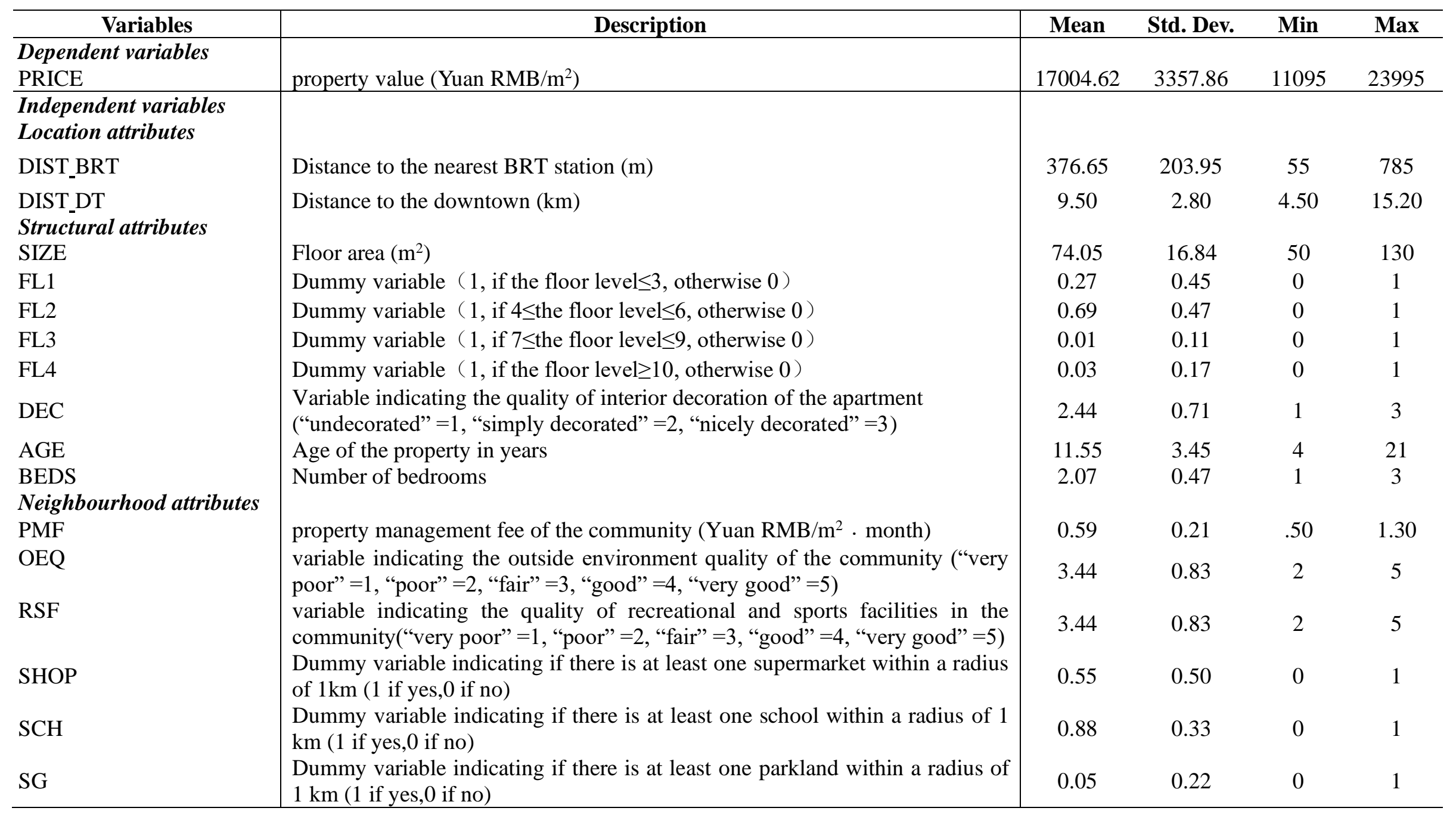

Note: The assignments on ratings of 1-5 is collected by looking through for sale advertisements. 
Table 3: Hedonic Price Model results: factors influencing property values

\begin{tabular}{|c|c|c|c|c|c|c|}
\hline \multirow[t]{2}{*}{ Variable } & \multicolumn{3}{|c|}{ OLS robust errors } & \multicolumn{3}{|c|}{ Weighted least squares } \\
\hline & Coefficients & Std. Err. & $\mathrm{t}$-Statistics & Coefficients & Std. Err. & $\mathrm{t}$-Statistics \\
\hline \multicolumn{7}{|c|}{ Location attributes } \\
\hline DIST_BRT & $-0.0001394 * * *$ & 0.000025 & -5.59 & $-0.0001319 * * *$ & 0.0000209 & -6.32 \\
\hline DIST_DT & $-0.05486 * * *$ & 0.0019871 & -27.61 & $-0.0542743 * * *$ & 0.0019536 & -27.78 \\
\hline \multicolumn{7}{|c|}{ Structural attributes } \\
\hline $\begin{array}{l}\text { SIZE } \\
\text { FL1 }\end{array}$ & 0.0001671 & 0.0002783 & 0.60 & $\begin{array}{l}0.0002759 \\
0.0020068\end{array}$ & $\begin{array}{c}0.0003566 \\
0.043481\end{array}$ & $\begin{array}{l}0.77 \\
0.05\end{array}$ \\
\hline FL2 & $0.0248361 * *$ & 0.0096407 & 2.85 & 0.029337 & 0.0415329 & 0.71 \\
\hline FL3 & -0.0137558 & 0.0226216 & -0.61 & & & \\
\hline FL4 & -0.0210948 & 0.0232548 & -0.91 & -0.0067016 & 0.0445555 & -0.15 \\
\hline DEC & 0.0022148 & 0.0045755 & 0.48 & 0.0031219 & 0.0051642 & 0.60 \\
\hline AGE & $0.0032792 * * *$ & 0.0010833 & 3.03 & $0.0032094 *$ & 0.0017115 & 1.88 \\
\hline BEDS & 0.0152044 & 0.0115788 & 1.31 & 0.0093302 & 0.0132734 & 0.70 \\
\hline \multicolumn{7}{|c|}{ Neighbourhood attributes } \\
\hline PMF & $-0.0503385^{* *}$ & 0.0244685 & -2.06 & -0.0410348 & 0.0278286 & -1.47 \\
\hline OEQ & $0.083023 * * *$ & 0.0066785 & 12.43 & $0.0857437 * * *$ & 0.0070378 & 12.18 \\
\hline SHOP & 0.0206054 & 0.0135244 & 1.52 & $0.0220392^{*}$ & 0.0122469 & 1.80 \\
\hline $\mathrm{SCH}$ & 0.0220781 & 0.0159978 & 1.38 & 0.0188822 & 0.0125306 & 1.51 \\
\hline SG & $0.0340538 * * *$ & 0.0122556 & 2.78 & $0.0404147^{*}$ & 0.0205943 & 1.96 \\
\hline _cons & $9.902149 * * *$ & 0.0397628 & 249.03 & $9.879091 * * *$ & 0.0550128 & 179.58 \\
\hline$R$-squared & \multicolumn{3}{|c|}{0.9402} & \multicolumn{3}{|c|}{0.9334} \\
\hline
\end{tabular}

Notes: $* * *, * *$, and $*$ denote significance at the $1 \%, 5 \%$, and $10 \%$ levels, respectively The $t$-statistics for the coefficients are reported in parentheses.

The dependent variable (property prices) is in log form.

Variables of FL1, FL3 and RSF were omitted in the regression because of collinearity. 
Table 4: Comparison of proximity effects to BRT systems in Beijing, Bogotá and Seoul

\begin{tabular}{|c|c|c|c|}
\hline BRT system & Beijing BRT & Bogotá TransMilenio & Seoul BRT \\
\hline $\begin{array}{l}\text { Network of corridors } \\
\text { (at the time the study was } \\
\text { conducted) }\end{array}$ & $\begin{array}{l}3 \text { lines, but no } \\
\text { interconnections }\end{array}$ & $\begin{array}{l}\text { over } 42.5 \mathrm{~km} \text { of } \\
\text { exclusive busways on } \\
\text { two corridors }\end{array}$ & $\begin{array}{l}74 \mathrm{~km} \text { of median-lane } \\
\text { BRT services spanning } \\
8 \text { corridors }\end{array}$ \\
\hline Began full operation & December 2005 & December 2000 & July 2004 \\
\hline $\begin{array}{l}\text { Operation period } \\
\text { (at the time the study was } \\
\text { conducted) }\end{array}$ & over 6 years & a year and 4 months & over 3 years \\
\hline Operational mode & trunk-only lines & trunk-feeder system & trunk-feeder system \\
\hline $\begin{array}{l}\text { Peak ridership } \\
\text { (passengers/hr/direction) }\end{array}$ & 3800 & 34000 & 8400 \\
\hline $\begin{array}{l}\text { Average operating speed } \\
(\mathrm{km} / \mathrm{h})\end{array}$ & 21 & 23 & 22 \\
\hline Access measurement & straight-line distance & network distance & network distance \\
\hline Proximity impacts & $\begin{array}{l}\text { For every } 100-\mathrm{m} \\
\text { closer to the BRT } \\
\text { station, property } \\
\text { prices increase by } \\
\text { between } 1.32 \% \text { and } \\
1.39 \% \text {. }\end{array}$ & $\begin{array}{l}\text { For every } 100-\mathrm{m} \\
\text { closer to the BRT } \\
\text { station, property prices } \\
\text { increase by between } \\
1.86 \% \text { and } 2.54 \% .^{*}\end{array}$ & $\begin{array}{l}\text { Within } 300 \text { metres of } \\
\text { BRT stations, } \\
\text { residential land values } \\
\text { gained premiums } \\
\text { ranging from } 5 \% \text { to } \\
10 \% \text {. }\end{array}$ \\
\hline
\end{tabular}

Source: based on data from Rodi'guez and Targa (2004), Cervero and Kang (2011)

* Caculated by authors of this paper.

In Rodíguez and Targa (2004)`s study, walking speeds was assumed to be $4.39 \mathrm{~km} / \mathrm{h}$. 